\title{
Chapter 1 \\ Problem of Residue Management Due to Rice Wheat Crop Rotation in Punjab
}

\begin{abstract}
Punjab agriculture supported by input and output price structure and superior yields of rice and wheat compared to other crops has virtually become a rice-wheat monoculture. The rice-wheat cycle has led to over exploitation of ground water resources in the state. Use of combined harvester has further exacerbated the problem of crop residue management as it leaves behind a large amount of rice residue to be burnt in the open fields. This study brings the problem of agriculture waste burning in the forefront. It tries to enumerate the amount of pollution being caused by rice residue burning and its adverse impact on human health.
\end{abstract}

Keywords Rice-wheat crop rotation - Combined harvester - Residue burning • Residue management

\subsection{Agricultural Growth in Punjab}

The Indian state of Punjab is known as the country's chief granary contributing almost one-fourth share of rice and more than one-third of wheat to the central pool. On an average, the state's share in the total production of wheat and rice in all-India stands about 20 and $10 \%$, respectively. Table 1.1 provides details of wheat and rice contribution by Punjab to the central pool over the last three decades. Further, above $95 \%$ of food grains produced in the state go out of the state to feed food deficit areas through the public distribution system. The state agriculture is characterized as the backbone of the public distribution system and a strong base for the food security of the country.

Punjab made a commendable progress in the production of food grains in the post-green revolution period. Food grain production underwent a big jump from 3.16 million tonnes in 1960-1961 to 28.35 million tonnes in 2011-2012. The green revolution also known as the new agricultural strategy was marked with the arrival of new high yielding varieties of wheat, rice, maize and bajra (millet) and package of other inputs like chemical fertilizers, insecticides, pesticides and 
Table 1.1 Contribution of wheat and rice to the central pool by Punjab

\begin{tabular}{|c|c|c|}
\hline Period & Percent share of rice & $\begin{array}{l}\text { Percent share of } \\
\text { wheat }\end{array}$ \\
\hline 1980-1981 & 45.3 & 73.0 \\
\hline 1990-1991 & 41.0 & 61.0 \\
\hline 2000-2001 & 33.3 & 57.6 \\
\hline $2005-2006$ & 32.0 & 60.9 \\
\hline $2006-2007$ & 31.2 & 75.3 \\
\hline $2007-2008$ & 27.8 & 60.9 \\
\hline 2008-2009 & 25.1 & 43.8 \\
\hline $2009-2010$ & 29.0 & 42.3 \\
\hline $2010-2011$ & 25.2 & 45.3 \\
\hline 2011-2012 & 22.1 & 38.7 \\
\hline $2012-2013$ & - & 33.6 \\
\hline
\end{tabular}

Source Statistical abstracts of Punjab, various years

assured irrigation facilities. Focusing on popularizing modern inputs and practices in the productive areas where the likelihood was more for the high yielding seeds to show results was the most important feature of this new strategy. Punjab with requisite irrigation and infrastructure facilities became a major beneficiary of this national strategy and has been shown as a showpiece of India's successful green revolution strategy. Short duration and high yielding varieties (HYV) of rice and wheat were introduced in Punjab to boost up the production of food grains. During the first decade of the green revolution, the technology was confined only to the wheat crop. A remarkable growth rate of $5 \%$ was achieved by the state's agricultural sector since the beginning of the green revolution in the mid-1960s.

The decade from the mid-1970s to mid-1980s was characterized by the extension of new seed fertilizer technology from wheat to rice crop. Due to the input and output price structure and superior yields of rice and wheat as compared to other crops, Punjab agriculture has virtually become a rice-wheat monoculture. During 1966-1967, total area under rice was 0.29 million hectares, which increased to 2.82 million hectares by 2011-2012. There was also a substantial increase in the average rice productivity, which increased from $1,186 \mathrm{~kg} / \mathrm{ha}$ in 1966-1967 to 3,741 kg/ha by 2011-2012 (Fig. 1.1). During the same period, the area under wheat crop increased from 1.61 million hectares to 3.51 million hectares and productivity from 1,544 to $4,898 \mathrm{~kg} / \mathrm{ha}$. Punjab has achieved a crop intensity of $188 \%$ as against 138 in the country as a whole. The present level of consumption of fertilizer (NPK) is $244 \mathrm{~kg} / \mathrm{ha}$ as compared to the Indian average of $144 \mathrm{~kg} / \mathrm{ha}$. Similarly, Punjab has $98 \%$ of high yielding variety coverage, which is the highest among the Indian states. About $18 \%$ of the total tractors in India are in Punjab. Production is supported by about $97 \%$ irrigation coverage with 970,139 tube wells.

Given tremendous achievements in the past, however serious concerns are now emerging about the future prospects of Punjab's agricultural sector. Agricultural growth slowed substantially in the 1990s. Agricultural output grew at a trend rate 


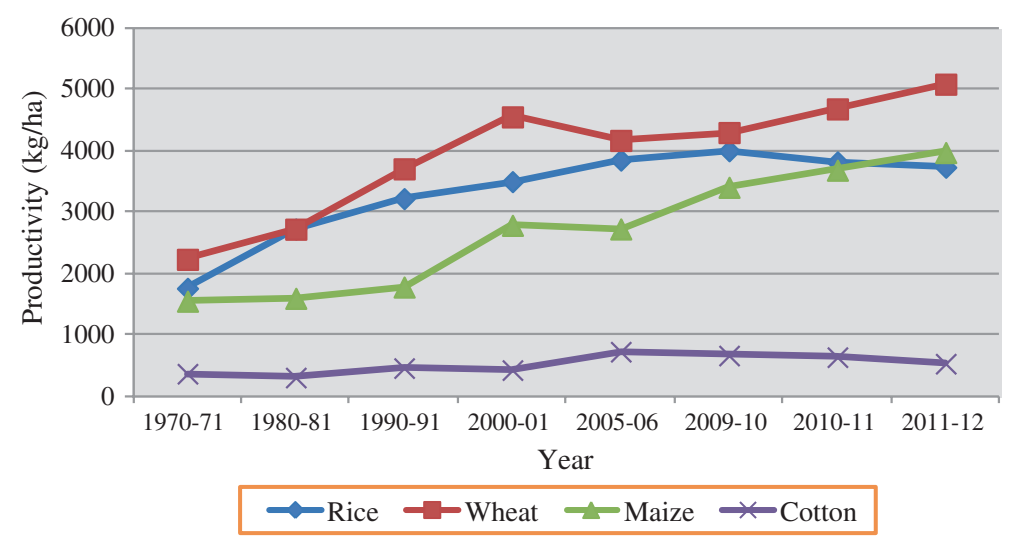

Fig. 1.1 Productivity of major crops in Punjab

of $2.6 \%$ per annum in the 1990 s compared to the all India average of $3.2 \%$ and relative to a growth rate of $5 \%$ per annum in Punjab in the 1980s. Productivity of rice appears to be reaching to plateau. The main rice-wheat tract of central Punjab also experienced a decrease in growth with total factor productivity (TFP) growth coming down to $0.07 \%$ per annum mainly due to negative TFP growth in rice (Singh and Hussain 2002).

\subsection{Agricultural Residue Burning and Its Management}

The growth story of Punjab agriculture was accompanied by its negative environmental concerns. One of the concerns is about the over exploitation of ground water resources of the state. Punjab now has the highest percentage of ground water exploitation in the country and also the largest percentage of over exploited and dark blocks. As per the guidelines of Ground Water Resources Estimation Committee (GEC), the present ground water development (ratio of gross ground water draft for all uses to net ground water availability) in the state is $145 \%$ as on March 2004. As per latest data provided by Central Ground Water Board, (Government of India 2011) and Department of Irrigation Punjab, ${ }^{1}$ out of 137 blocks of the state, 103 blocks are overexploited, 5 blocks are critical, 4 blocks are semi critical and only 25 blocks are in safe category. All the blocks of various districts like Amritsar (16 blocks), Jalandhar (10 blocks), Moga (5 blocks), Kapurthala (5 blocks), Sangrur (12 blocks), Fatehgarh Sahib (5 blocks), Patiala (8 out of 9 blocks) and Ludhiana (9 out of 10 blocks) have been found to be overexploited, leading to sharp depletion of the water table in these districts.

\footnotetext{
${ }^{1}$ Report on dynamic ground water resources of Punjab, 2005, Government of Punjab.
} 
Another issue of concern is that water in a large part of the area, which indicates positive ground water balance, is saline and hence unfit for consumption. It is important to take cognizance of the fact that central Punjab has $72 \%$ area under paddy cultivation, out of which only $21 \%$ area has canal water irrigation facility. Over $6 \%$ of the total tube wells in India are in Punjab. Tube wells in the central districts of the state constitute around $70 \%$ of total tube wells in Punjab, which have increased from 0.192 million constituting 0.09 million electric and 0.10 million diesel operated in 1970-1971 to 1.17 million with 0.88 million electric and 0.29 million diesel operated in 2004-2005. ${ }^{2}$ Hence, the cultivation of high waterdemand crops is an important factor contributing towards declining water levels in Punjab. It can be observed that the present grim scenario of ground water in different regions of the state is essentially the outcome of unscrupulous production practices leading to excessive and irrational use of water particularly for rice crop. Other factors include less than required availability of surface water, free power supply to the agricultural sector, support prices and procurement facilities for only some crops and disproportionate installation of tube wells by farmers.

Further, in the past two to three decades, intensive agricultural practices have put a tremendous pressure on the soils and resulted in steady decline in its fertility and nutrient availability both with respect to macro and micronutrients. Both, rice and wheat have high nutritional requirements and the double cropping of this system has been heavily depleting the nutrient contents of soil. For example, a rice-wheat sequence that yields $7 \mathrm{t} / \mathrm{ha}$ of rice and $5 \mathrm{t} / \mathrm{ha}$ of wheat removes more than $300 \mathrm{~kg}$ nitrogen, $\mathrm{N}, 30 \mathrm{~kg}$ phosphorus, $\mathrm{P}$ and $300 \mathrm{~kg}$ of potassium, $\mathrm{K}$ per hectare from the soil. Even with the recommended rate of fertilization in this cropping pattern, a negative balance of primary nutrients still exists (Benbi et al. 2006). Moreover, the partial factor productivity of NPK in Punjab has also dropped from 80.9 in 1966-1967 to 16.0 in 2003-2004. Hence, farmers in the state have been applying higher and higher doses of major nutrients, especially nitrogen for sustaining adequate production levels. Extensive use of nitrogenous fertilizers and pesticides has also led to increasing nitrate concentration and accumulation of pesticide residues in soil, water, food, feed and other agricultural produce often above tolerance limits.

Following the success of the high yielding varieties, there was introduction of rice-wheat cropping pattern in Punjab. It covers more than 2.6 million hectares or $60 \%$ of the total net sown area of the state (Government of Punjab 2005). With the adoption of rice wheat cropping pattern in the state, crop diversity has decreased considerably and area under crops like, gram, pulses, groundnut, etc., which have a positive impact on soil quality, has decreased. Also, area under low input crops, like maize, bajra, jowar (sorghum), etc., have also decreased (Table 1.2).

Under the rice-wheat cropping pattern, rice has to be harvested early in order to accommodate the wheat crop. This means, a very little time is left in the hands of the farmers to turn around for planting the wheat crop. Within this period, the

\footnotetext{
${ }^{2}$ Statistical Abstract of Punjab, (Government of Punjab 2005).
} 
Table 1.2 Cropping pattern in Punjab (GCA in thousand hectares) (Area under various crops as percentage of gross cropped area)

\begin{tabular}{|c|c|c|c|c|c|c|c|c|}
\hline Crop & $\begin{array}{l}1960- \\
1961\end{array}$ & $\begin{array}{l}1970- \\
1971\end{array}$ & $\begin{array}{l}1980- \\
1981\end{array}$ & $\begin{array}{l}1990- \\
1991\end{array}$ & $\begin{array}{l}2000- \\
2001\end{array}$ & $\begin{array}{l}2006- \\
2007\end{array}$ & $\begin{array}{l}2010- \\
2011\end{array}$ & $\begin{array}{l}2011- \\
2012\end{array}$ \\
\hline Rice & 4.79 & 6.87 & 17.49 & 26.86 & 32.89 & 32.90 & 35.72 & 35.62 \\
\hline Wheat & 29.58 & 40.49 & 41.58 & 43.63 & 42.92 & 44.00 & 44.36 & 44.59 \\
\hline Maize & 6.91 & 9.77 & 4.50 & 2.44 & 2.08 & 1.94 & 1.68 & 1.59 \\
\hline $\begin{array}{l}\text { Bajra and } \\
\text { jowar }\end{array}$ & 2.72 & 3.73 & 1.03 & 0.16 & 0.08 & 0.13 & 0.04 & 0.04 \\
\hline $\begin{array}{l}\text { Cotton } \\
\text { (American) }\end{array}$ & 5.17 & 3.73 & 7.42 & 8.49 & 4.51 & 7.22 & 5.94 & 6.40 \\
\hline $\begin{array}{l}\text { Cotton } \\
\text { (Desi) }\end{array}$ & 4.26 & 3.26 & 2.17 & 0.85 & 1.46 & 0.43 & 0.16 & 0.11 \\
\hline Sugarcane & 2.81 & 2.25 & 1.05 & 1.35 & 1.52 & 1.39 & 0.88 & 1.01 \\
\hline $\begin{array}{l}\text { Total } \\
\text { oilseeds }\end{array}$ & 3.90 & 3.96 & 3.52 & 1.39 & 1.08 & 0.81 & 0.49 & 0.47 \\
\hline $\begin{array}{l}\text { Total } \\
\text { pulses }\end{array}$ & 19.08 & 7.29 & 5.04 & 1.91 & 0.68 & 0.36 & 0.27 & 0.23 \\
\hline Barley & 1.39 & 1.00 & 0.96 & 0.49 & 0.40 & 0.24 & 0.15 & 0.15 \\
\hline Vegetables & - & 0.88 & 0.95 & 0.72 & 1.39 & 1.39 & 1.40 & 1.40 \\
\hline Fruits & - & 0.88 & 0.43 & 0.92 & 0.43 & 0.72 & 0.88 & 0.90 \\
\hline Other crops & 19.39 & 15.89 & 13.86 & 10.79 & 10.56 & 8.47 & 8.02 & 7.49 \\
\hline $\begin{array}{l}\text { Gross } \\
\text { cropped } \\
\text { area }\end{array}$ & 4,732 & 5,678 & 6,763 & 7,502 & 7,941 & 7,932 & 7,912 & 7,912 \\
\hline
\end{tabular}

Source Statistical abstracts of Punjab, various issues

farmer has to get rid of the rice stubble and prepare the land for sowing the wheat crop. The previous varieties of rice and wheat crops were of long duration and could fit rice-wheat rotation only in small areas. But with the availability of photoperiod non sensitive short duration varieties of wheat as well as rice it became possible to grow high yielding 120-130 days rice crop, i.e., June-July to OctoberNovember followed by a high yielding 110-120 days wheat crop, i.e., NovemberDecember to March-April. With the adoption of these varieties rice-wheat crop rotation was practiced in areas which formerly produced only wheat or rice but not both in the same field in any one farming year. The major constraint in the ricewheat cropping system is the available short time between rice harvesting and sowing of wheat and any delay in sowing adversely affects the wheat crop. Preparation of the field also involves removal or utilization of rice straw left in the field.

Various modern inputs were introduced in Punjab to harvest the rice crop within such a short period of time. One such input which has become the most popular implement in the rice-wheat cropping system is the use of the combined mechanized harvester. The use of the combined harvester has increased at a tremendous rate in Punjab. Almost $80 \%$ of the rice crop is harvested using this implement in Punjab. However, the use of the combined harvester has in reality 
exacerbated the problem of crop residue management. The use of combined harvesters leaves behind a large amount of rice residue to be burnt in the open fields. The combined harvester spreads the rice residue in the fields which is difficult to collect. It is widely perceived that farmers find it the easiest and the most economical way of getting rid of the rice stubble through burning it. Also, the shortage of time for sowing the wheat crop, after the rice crop harvest, leaves farmers with no other option but to burn it.

Thus, burning has emerged as the standard method of rice residue/stubble management in the combine harvested rice-wheat cropping system that is practised on a broad scale in the state of Punjab in northwest India. Every year almost 15 million tonnes of paddy straw are generated in Punjab. Of this, according to various estimates, on an average, almost 7-8 million tonnes of rice residue are set on fire in open fields.

Rice residue burning results in extensive impacts both on and off farm, e.g., losses in soil nutrients, soil organic matter, production and productivity, air quality, biodiversity, and water and energy efficiency and on human and animal health. In India, air pollution from residue burning can be severe, with impacts on human health by directly causing or exacerbating a range of health hazards and contributing to the incidence of traumatic road accidents through significantly reduced visibility. One of the recognized threats to the rice-wheat cropping system sustainability is the loss of soil organic matter as a result of burning. The straw collected from the fields is of great economic value as livestock feed, fuel and industrial raw material. In northern India, wheat straw is preferred while in Southern India paddy straw is fed to livestock (Hegde 2010). The residue generated from the ricewheat cropping system can be put to many uses, but this is possible if the residue is separated from the grain and carried out of the field. Burning reduces the availability of straw to livestock, which is already in short supply by more than $40 \%$. However, in the case of combine harvesting, most of the residue is left in the field for burning adversely affecting overall sustainability of the rice-wheat cropping system (Thakur 2003). Zero tillage after stubble burning is now being adopted by many farmers. In 2005-2006, around $10 \%$ of the total area sown under wheat was by using zero till machines. Apparently less than $1 \%$ of farmers incorporate the paddy straw because in the case of incorporation more tillage operations are required than after burning (Singh et al. 2008). The options for crop residue management may include developing systems to plant residue into bailing and removal for use as animal feed or for industry. Enhanced decomposition of machine-harvested straw to improve nutrients in the soil can be useful. The use of microbial sprays that can speed decomposition of residue is also an option. The option of planting into residue needs further investigation of inorganic nitrogen and its adverse effect due to nitrogen deficiency.

Though various studies in the literature have addressed this issue of burning of the crop stubble but none have brought to the forefront the adverse implications of this unwarranted practice on human and animal health. The study proceeds first by bringing to the forefront the amount of pollution being caused by rice residue burning. Thereafter the harmful effects of the pollution being generated by rice 
stubble burning on human health are studied. Based on the information obtained, we analyse the Punjab government's existing policies to address air pollution caused by rice stubble burning. What policies have the Punjab government put in place to prevent this practice? Are there any bottlenecks in the actual implementation of these policies? What are the current mechanisms in place for recording and monitoring the pollution caused by crop stubble burning? Based on the findings of the Punjab government policies to address the pollution caused by crop stubble burning, the study aims to provide policy suggestions to remove the practice.

The study aims to estimate the monitory value of health effect of crop stubble burning in rural Punjab. However, it needs to be highlighted here that crop stubble burning leads to various losses including loss in soil nutrients, soil organic matter, productivity of soil, water and energy efficiency in addition to its adverse impact on human and animal health and its impact on vegetation, air quality, environment and biodiversity. The subject matter of the present study only deals with the adverse impact of stubble burning on human health, which is measureable in monetary terms, e.g., the amount spent on treatment, medicine, cure and losses in working hours. The other losses mentioned above have not been attempted in this study and therefore such losses are beyond the subject matter of the present study and should be understood as a limitation of this study.

Based on the findings of the Australian Council of International Agriculture Research (ACIAR) Project, LWR/2006/124, 'Fine-tuning the Happy Seeder Technology for Adoption in the Northwest India' on the feasibility of the various alternatives to crop residue burning, and based on our own information collected from various departments of the Punjab government, the study analyses the viability of some alternative residue uses such as fodder for animals, fuel for the generation of electricity, etc. As part of the ACIAR project LWR/2000/089 (Permanent beds for irrigated rice-wheat and alternative cropping systems in northwest India and southeast Australia), a new generation of seeders capable of directly drilling wheat into heavy rice residue loads without prior burning was developed. These machines have been called Happy Seeders. Preliminary financial evaluation of the technology within LWR/2000/089 indicates that adoption of the technology can be both financially viable for farmers, and financially preferable to alternative residue management practices such as residue incorporation or residue burning. In addition, preliminary economic evaluation of important external benefits associated with the use of the Happy Seeder, such as reduced public costs in the provision of fertilizer and irrigation water to farmers, suggests that there may be substantial gains for the broader community from adoption of the Happy Seeder in the form of lower levels of air pollution.

Existing policy settings and/or the way they are practically interpreted and implemented may constrain the adoption of the Happy Seeder technology by farmers. The ACIAR project PLIA/2006/180 (Happy Seeder policy linkage scoping study) assessed the range and scale of policy related issues for its adoption. The scoping study identified a range of constraints and recommended that more measures thorough financial and economic evaluation of the technology and its alternatives, and the assessment of potential policy instruments which could be used to enhance adoption, be undertaken. 
The ACIAR project proposal LWR/2006/124 (Fine tuning the "Happy Seeder" technology for adoption in northwest India) includes objectives to extend and further refine the financial evaluation of the Happy Seeder technology relative to options involving the burning or incorporation of rice residue. These financial evaluations are important in determining the viability and private incentive for adoption of the technology from the point of view of individual farmers, depending on farm size, cost structures, etc. However, these evaluations are not designed to inform policy interventions which may be necessary to enhance adoption to levels consistent with generating significant reductions in off-site impacts.

The present study aims to broaden the analysis beyond the farm and financial levels. It analyses off-site uses of rice residue; undertakes the analysis from a socio-economic rather than only financial perspective; For example, some proponents of the Happy Seeder currently favour enforcement of existing pollution laws which ban residue burning in combination with the provision of government subsidies to individual farmers to lower the initial capital cost of purchasing the Happy Seeder machinery. However, appropriate assessments have not been undertaken to demonstrate the relevant impact of agriculturally based pollution to broad-scale air pollution; the book addresses these questions.

This book is an outcome of the project carried out by the authors titled, 'Policy instruments to address air pollution issues in agriculture-Implications for Happy Seeder Technology Adoption in India'. The project was funded by the ACIAR and was carried out at the National Council of Applied Economic Research, New Delhi. The development of this project is in response to recommendations made within the ACIAR scoping study PLIA/2000/180 (Happy Seeder policy linkages scoping study). The scoping study identified a range of policy related constraints, in particular:

- An inadequate understanding of the financial viability of the technology over a range of farmers' socio-economic circumstances (often relating to farm size);

- The significant but unquantified external benefits that would accrue to the broader community from adoption of the Happy Seeder technology often relating to pollution reduction;

- A lack of analysis of the economic performance of the Happy Seeder technology relative to the performance of other off-site uses of rice residues; and,

- A focus by relevant state policy makers on the financial performance of the technology in their consideration of the need for government intervention to accelerate and increase adoption rather than focusing on both financial and economic performance.

As a consequence, the scoping study recommended that more comprehensive financial and socio-economic evaluation of the technology and its alternatives, and the assessment of a range of potential policy instruments which could be used to enhance adoption, be undertaken. The study offers a range of potential economic, social and environmental insights. Preliminary studies show that the Happy Seeder technology may offer potential economic benefits over traditional residue burning 
activities in the rice-wheat production system. ${ }^{3}$ The Happy Seeder technology is relevant to a large area of the northwest Indo-Gangetic plains of India in which the rice-wheat production system predominates. It is proposed within the ACIAR project proposal LWR/2006/124 that if the Happy Seeder technology is utilized over $10 \%$ of the area currently under zero till plus burning regime in Punjab, it would result in potential financial benefits of Rs. 92 million (approximately, A\$2.7 million). Accounting for externalities would result in potential economic benefits of an even larger magnitude.

Overcoming impediments to the adoption of less polluting agricultural technologies will be of significant benefit to the broader community. Benefits will include reduction in a range of off-site impacts of residue burning, including those on human health, other industries, and adjacent communities, especially smokerelated illness, transport disruption, etc. Social benefits will accrue from designing government adoption incentives which better account for the range of socio-economic circumstances of rice-wheat farmers in Punjab.

Along with reduction in air and water pollution, higher levels of adoption of less polluting agricultural technologies ensure improvements in soil health, primarily through improvements in soil nutrient levels and soil organic matter, and reductions in the irrigation water and electricity demands for groundwater pumping in the rice-wheat production system. Biodiversity conservation also gets enhanced through a decline in residue burning as it reduces fire damage to adjacent remnant vegetation and wildlife habitat including nationally significant species.

The analysis gauges the relative significance of policies and other drivers of changes in residue management practices, research and/or development strategy. The study aims to resolve policy issues identified in the ACIAR project PLIA/2006/180 (Happy Seeder policy linkage scoping study). The Happy Seeder technology was developed and proof of concept achieved in the ACIAR project LWR/2000/089 (Permanent beds for irrigated rice-wheat and alternative cropping systems in northwest India and southeast Australia).

The study targets air pollution issues in agriculture within the state of Punjab. Its findings and recommendations will be useful and relevant to policy makers and analysts from organizations such as the Punjab Pollution Control Board, Punjab State Department of Agriculture, and Punjab State Council for Science and Technology. The Punjab government has recently established a government taskforce on air pollution/residue burning, chaired by the Director of the Punjab Pollution Control Board. The taskforce is keenly interested in the findings of the

\footnotetext{
3 The results of the financial analysis indicate that the present value of total financial benefits from adoption of the Happy Seeder in comparison to residue burnt/zero tillage wheat are Rs. 10,150/ha higher (A $\$ 299$ ), and Rs. 32,750/ha (A $\$ 963 /$ ha) higher than the residue burnt/conventional tillage option. When economic values are incorporated for the water use efficiency related cost savings, the benefits of the Happy Seeder are further increased to Rs. 20,000/ha (A\$588/ha) and Rs. 42,500/ha (A \$1,250/ha) over these other options, respectively (Sidhu et al. 2007).
} 
study, as the mandate of the taskforce is to draft a policy on residue burning and pollution issues in Punjab agriculture.

Results of the Australian component of the project directly communicate to policy makers within the NSW Department of Primary Industries (DPI) and the NSW Department of Environment and Climate Change (DECC). These agencies have primary interests and responsibilities for the development of sustainable practices and natural resource management policies. The findings and recommendations would be relevant to manage crop residue concerns for rice, with most of the Australian rice industry being located in NSW, and other crops.

\subsection{Main Objectives of the Study}

The study focuses on environmental policy issues associated with rice residue burning. The main objectives of the study are:

1. Assess the broader significance of agriculture-based pollution in Punjab and describe existing and proposed policies.

2. Evaluate the cost of pollution caused by agricultural waste burning to the society at large and suggest a range of potential alternate uses of rice/wheat stubble.

3. Review the relative significance of policies and technologies in changing residue management practices in Punjab.

Assessment undertaken in addressing above objectives was completed though the review of existing secondary data, reports and publications and through interviews and discussions with concerned policy makers and analysts. For the assessment of economic valuation of pollution on human health, a primary household survey of 150 households was carried out in three villages in the Patiala district. The details of methodology are provided in each of the chapters. The review of the technology context associated with historical reductions in burning as a residue management practice in India has been undertaken through the review of reports and publications relating to technological change in this area, and of its adoption by Indian farmers. Review of the policy context was done through analyses of historical legislative changes and government programmes and incentives, available published and unpublished relevant documents, and through interviews and discussions with Punjab government officials.

\subsection{An Overview}

The book includes seven chapters including the introduction to the study. This chapter also lays down the details of genesis of this study and puts forth the main objectives for which the study was undertaken, and the methodology followed and 
data used in meeting with those objectives. Chapter 2 gives an overview of management of crop stubble. The chapter introduces the extent of pollution caused by crop stubble burning, citing various examples from the literature, its effect on fertility of soil, impact on human health and available different methods of crop stubble management as cited in the literature and alternative uses of crop stubble. Chapter 3 deals with evaluating the health effects of air pollution from agricultural residue burning. This chapter presents the details of the design of the household survey in the three selected study villages followed by presentation of ambient air quality levels in the villages during the period when harvesting of rice take place. Subsequently, some details of the agricultural output (productivity) among the selected households and some health indicators are presented in the chapter followed by theoretical model and estimation strategy and the results on monetary estimates of health consequences of air pollution.

Chapter 4 looks at the alternative uses of crop stubble. The chapter starts with presenting disposal pattern of paddy straw giving details of alternate uses of agriculture waste, viz., rice residue as fodder for animals, its use in bio-thermal power plants, its use for bedding material for animals, mushroom cultivation and so on. The chapter discusses in details of residue use in power generation citing various bio-mass power projects commissioned in the state by the Punjab Energy Development Agency (PEDA).

Chapters 5 and 6 present details of environment legislation in the state as well as the country as a whole and the Punjab government's policy to tackle the problem of agricultural waste burning. Chapter 5 discusses the legislation on pollution in India in general and Punjab in particular. The chapter presents various laws to control pollution like Water Act 1974, Air Prevention and Control of Pollution Act 1981, Environment Protection Act 1986, National Environment Tribunal Act 1995, Noise Pollution Rules 2000, Bio-diversity Act 2000 and so on. The chapter also discusses various functions and activities of Central Pollution Control Board, Punjab Pollution Control Board, Punjab State Council for Science and Technology, Punjab Energy Development Agency and Punjab Bio Diversity Board. Chapter 6 analyses Punjab government policies for restricting the agriculture residue burning. The chapter discusses the role being played by different organs of Punjab government in controlling agriculture waste burning, especially to mention, Punjab Pollution Control Board, Agricultural Councils, Punjab State Council for Science and Technology, Department of Agriculture, Department of Animal Husbandry, Punjab Energy Development Agency, Punjab Agricultural University, Punjab State Farmers' Commission, Department of Rural Development and panchayats (local governments). Chapter 7 offers summary conclusions and policy suggestions.

Open Access This chapter is distributed under the terms of the Creative Commons Attribution Noncommercial License, which permits any noncommercial use, distribution, and reproduction in any medium, provided the original author(s) and source are credited. 


\section{References}

Benbi, D. K., Nayyar, V. K., \& Brar, J. S. (2006). The green revolution in Punjab: Impact on soil health. Indian Journal of Fertilizers, 2(4), 57-66.

Government of India. (2011). Dynamic groundwater resources of India. Faridabad: Central Ground Water Board, Ministry of Water Resources, Government of India.

Government of Punjab. (2005). Economic and Statistical Organization, Statistical Abstract of Punjab.

Hegde N. G. (2010). Forage resource development in India. In: Souvenir of IGFRI Foundation Day, November, 2010. www.baif.org.in.

Singh, J., \& Hussain, M. (2002). Total factor productivity analysis and its components in a high potential rice-wheat system: A case study of the Indian Punjab. In M. Sombilla, M. Hussain, \& B. Hardy (Eds.), Developments in Asian rice economy. Manila: IRRI.

Sidhu, H. S., Singh, M., Humphreys, E., Singh, Y., Singh, B., Dhillon, S. S., (2007). The Happy Seeder enables direct drilling of wheat into rice stubble. Australian Journal of Experimental Agriculture,47(7), 844-854.

Singh RP, Dhaliwal HS, Humphreys E, Sidhu HS, Singh M, Singh Y, John B (2008) Economic Assessment of the Happy Seeder for Rice-Wheat Systems in Punjab, India. A paper presented at AARES 52nd annual conference, Canberra, ACT, Australia.

Thakur, T. C. (2003). Crop residue as animal feed: Addressing resource conservation issues in rice-wheat systems of south Asia, a resource book. Rice Wheat Consortium for Indo-Gangetic Plains (CIMMYT), March, 2003. 